\title{
Strengthening the Legislature for Effective Performance at the Third Tier of Government in Nigeria
}

\author{
Aliyu, M. Kolawole, $\mathrm{PhD}$ \\ Department of Political Science, Obafemi Awolowo University, Ile-Ife, Osun State, Nigeria \\ Bamidele Samson Olukayode, $\mathrm{PhD}$ \\ Department of Political Science, Bamidele Olumilua University of Education, Science and Technology, \\ Ikere-Ekiti
}

\begin{abstract}
The legislature is a vital organ of government in a democratic regime just as the executive and the judiciary. Unfortunately, the legislature at local government level in Nigeria has become moribund to deliver its vital roles due to a number of challenges such as party politics, appointment of caretaker members into council areas, use of local-state joint account, overbearing of the state government(s) on grassroots activities, and so on. As a result of the above challenges, the legislature at the third tier of government needs to be repositioned for effective service delivery. Hence, this paper examines the challenges of the legislature at the third tier of government with a view to making it more assertive to deliver on its constitutional roles. The study adopts qualitative method in its investigation. Data for the study were gathered from secondary sources and were content analyzed. The study revealed that the legislative activities at the grassroots in Nigeria are below expectation. This paper concludes that if the legislative arm of government is properly strengthened at the grassroots, it is capable of enabling people to receive urgent attention, assist in public engagement, reduce marginalization, and convey higher degree of legitimacy on the legislators for decision making.
\end{abstract}

Keywords: strengthening, the legislature, effective performance, service delivery, third tier of government.

DOI: $10.7176 / \mathrm{DCS} / 11-4-05$

Publication date: April $30^{\text {th }} 2021$

\section{Introduction}

The administration of local government in Nigeria is one of the oldest efforts at making the grassroots to enjoy closer governance. The earliest local governments existed in the form of clans and villages. In other parts of the world, local governance was developed along the people's culture and expectations, and the system was tied to the norms and practices of the people (Mishael, 2016). In Nigeria, local government operates a presidential system in which the chairman of the local government council is directly elected by eligible voters in the local government area and governs in collaboration with the legislative arm of government. Local council members are elected from single member wards while the term of both the chairman and the legislature is currently three years, but varies from state to state based on the legislation by the state house of assembly (Diejomaoh and Eboh, 2010). Nigeria adopts a federal system with a constitutional arrangement that recognizes three tiers of government which are federal, state and local governments. These tiers of government have functions which arc to some extent, independent and clearly specified in the 1999 constitution of the federal republic of Nigeria (Fourth Schedule of 1999 Constitution of the Federal Republic of Nigeria).

Local government refers to the government at the grassroots level, recognized by law, having local representatives and power to enforce tax and extract labour within a specific jurisdiction for the purpose of efficient service delivery and political mobilization toward enhancing development (Adeyemo, 2005). According to Orewa and Adewurni (1992), the mandate of local government is to pilot the affairs of local council with recognizable arms of government. The reasons for creation of local government in any country, according to Ogbuene and Nzelibe (1991) and Apata (2011) include, but not limited to economic viability and bringing people of the same culture together and for socio-political development. In the view of Adoti (2017), three basic reasons for establishing local government in Nigeria are: one, to develop activities and make appropriate services. Two, to bring the model of democratic self-governance and facilitate the leadership potential of Nigerians on local levels, and three; to gather human and material resources and involve them in their local government.

There are thirty six states in Nigeria with a federal capital territory in Abuja. These states are also subdivided into 774 local government areas. These areas reflect the local development of the Nigerian federative system. Also, the adoption of this federative system contributed to the distribution of authority to the local councils. Thus, grassroots government is a medium for political mobilization that provides efficient service delivery to local inhabitants (Danjuma, 2012). The 1999 constitution formed the institutional framework for local government system in Nigeria. Its Section 8 states that "the government of every state shall subject to the provisions of this constitution ensure their existence under a law which provides for the establishment, structure, 
composition, finance and functions of such couni1s"

The 1999 constitution equally ensures that local governments consolidate the tripartite organs of government, which are the executive, legislature and judiciary. As explained by Diomaoh and Eboh (2010), executive powers arc vested in the chairman, vice-chairman, supervisor or supervisory concillors, as well as the structure of local government bureaucracy. The legislative functions are meant to be performed by the councilors, who represent the wards which make up the local government area. The judiciary on the other hand, is streamlined along with the federal and state governments in order to avail it the judicial process. Because of the need for the existence of rules that will guide the behaviour of individuals and institutions within the council areas, the legislature is charged with the primary responsibility of making laws for local government (Nwoba, ojo and Tiben, 2015). Local government legislators are therefore elected body charged with the primary responsibility of formulating the laws that govern the council areas. Although, local government legislature in Nigeria has the primary responsibility of rule-making; they nevertheless perform other oversight functions.

Thus, the legislature at the local councils in Nigeria refers to the councilors. The role of councilors covers the totality of issues that affects the local government council in general and' their constituents in specific. They serve as the mouth-piece of' the council and oversights the executives to ensure that the funds are judiciously spent, and other sundry matters arc quickly attended to for the overall development of the people at the grassroots. Similar to what the louse of assembly and national assembly members do at the state and national levels respectively, councilors represent their wards at the legislative arm of government (Adedayo, 2014). Local government system by democratically elected members is guaranteed by Section 7 of the 1999 constitution of the federal republic of Nigeria. The Fourth Schedule provides for the functions of a local government council. According to the Fourth Schedule, the main functions of a local government council are as follows: (a) the consideration and the making of recommendations to a state commission on economic planning or any similar body on (i) the economic development of the state, particularly in so far as the areas of authority of the council and of the state are affected, and (ii) proposals made by the said commission or body (b) collection of rates, radio and television licenses (c) establishment and maintenance of cemeteries. Burial grounds and homes for the destitute or infirm (d) licensing of bicycles, trucks (other than mechanically propelled trucks), canoes, wheel barrows and carts (e) establishment, maintenance and regulation of slaughter houses, slaughter slabs, markets, motor parks and public conveniences (f) construction and maintenance of roads streets, street lightings, drains and other public highways, parks, gardens, open spaces, or such public facilities as may be prescribed lime to lime by the House of Assembly of a State (g) naming of roads and sewage and numbering of houses (h) provision and maintenance of public conveniences. .vase and refuse disposal (i) Registration of all births, deaths and marriages $(\mathrm{j})$ assessment of privately owned houses or tenements for the purpose of levying such rates as may he prescribed by the House of Assembly of a State: and (k) control and regulation of: (i) out-door advertising and hoarding (ii) movement and keeping of pets of all description (iii) shops and kiosks (iv) restaurants, bakeries and other places for sale (v) laundries, and (vi) licensing, regulation and control of the sale of liquor. Under section 2 of the Fourth Schedule, the functions of a local government council shall include participation of such council in the government of a state in respect of the following matters: (a) The provision and maintenance of primary, adult and vocational education (b) The development of agriculture and natural resources, other than the exploitation of minerals (c) The provision and maintenance of health services; and (d) Such others functions as may he conferred on a Local Government Council by the House of Assembly of the State (Isa, 2015).

The above functions are easier to perform in a democratic setting. Unfortunately, the running of local government through sole administrator (caretaker) throws away the legislative organ and denied the people the opportunity of electing their representatives and holding them accountable. Moreover, as Haque (2012) argues that the basic foundation for political leadership is provided by local government, especially for people who are interested in pursuing their political career at higher levels. Unfortunately, the absence of legislative politics due to "care taker" or "sole administrator" system at the local level is a denial of the training opportunity for higher political leadership. Despite the justification for the establishment of legislative organ at the grassroots level, its absence has been severely felt in the areas of poverty and hunger, primary education, gender equality, women empowerment and primary health care.

The legislature has not justified the reasons for which it was established. It is pathetic that the activities of council parliament are not felt or seen. People at the grassroots do not perceive the local government legislators as taking part in local government elections. Councilors are absent in the local government areas they supposed to serve. They are not on ground to help the people when there is a challenge that calls for their intervention. They do not respond to the needs of the people because they are not on ground. It is evident that the people have not heard of the activities of the councilors at the grassroots. Instead, most communities make use of Community Development Association (CDA) that is made up of landlords and residents to resolve issues with local government. It is evident that there has not been much of service delivery on the part of local government legislature. Existing studies only paid transient attention to the study of the legislative performance at the third 
tier of government in Nigeria. This study will therefore contribute to the ongoing debates on how to strengthen the legislature for effective performance at local government level.

\section{Objectives of the Study}

This study is guided by the following research objectives. In other words, the study:

i. examines the statutory functions of the legislature as a vital arm of government at the local government in Nigeria;

ii. interrogates the challenges militating the legislature from performing its statutory functions;

iii. provides policy options on what should be done to strengthen the legislature for effective performance of its functions at the grassroots in Nigeria.

\section{Methodology}

This study adopts qualitative method in carrying out its investigation and used content analysis in its discussion. The data employed for the study were gathered from secondary sources wherein journal articles, newspapers, periodic papers and documentary materials among others were reviewed.

\section{Theoretical Framework}

This study adopts participatory theory for its explanation. The theory is traced to an Athenian leader Solon in the 8th century while some of its proponents are Oscar Wilde. Emma Goldman and James S. Fishkin ans so on (Wikipedia). This theory holds that local governments exist to bring about democracy and to afford the citizens the opportunities for political participation, training in the art of self-government and for political education and socialization (Adeyemo, 2011). As espoused as well by Ani et al (2013), local government involves a philosophical commitment to democratic participation in the politics and governing process at the grassroots level. In effect, local government does not only offer opportunities for political participation but constitutes a training ground for state or national positions. It is apt to say that participation is done at local levels through the elected representatives (councilors inclusive) from the various wards. Therefore, any decision made have binding effect on the whole community. In essence, the elected councilors are the mouthpiece of the grassroots because in a representative democracy, the legislature is seen as the representative of the people and occupies acceptable way to protect people's interests.

\section{The Mandate of the Legislature at Local Councils in Nigeria}

The legislature is made up of the "leader" of the councilors that is elected from a ward at the local council like other councillors. The councilors elect a leader among themselves to direct the business on issues affecting the council area similar to what is obtainable at the federal and state levels, that is, the National and State Houses of Assembly respectively. Legislative powers at the local government council arc exercised through bye-laws passed by the legislature and assented to by the chairman. It is the legislature that makes the bye-laws. The exclusive list on which a local government council is empowered to enact bye-laws upon are contained in section 1 (a), (b) of the fourth schedule of the 1999 constitution (as amended). The concurrent list which both a local government council and the state assembly have powers to legislate upon is in section 2 (a) and (b) of the fourth schedule. The legislature exercises its powers through resolutions and approvals in relation to individual or specific cases. That is, a resolution to remove the chairman or leader of the council by a two third majority. It also screens, approves and confirms the nominations of the chairman of the local government. It requires a simple majority of the legislature on the nomination of chairman of the local government as well as on the appointment of the vice chairman of the local government, in case of vacancy as a result of death, resignation or removal or other nominations. The legislature also debates, amends, and approves the annual budget of the local government. In addition, it vets and monitors the implementation of projects and programmes in the annual budget of the local government. It is also the mandate of the legislature to examine and debates the monthly statement of income and expenditure rendered to it by the chairman of the local government. It is expected to advise, consult and liaise with the chairman of the council on the progress made and perform such other functions that may be assigned to it from time to time by an edict or law of the state in which it is situated.

The legislature at local government is expected to legislate on all matters contained in the fourth schedule of the constitution so as to have good governance (Alobo, 2014). Thus, the emergence of legislative arm of government at the local government is traced to the 1976 local government reform. According to Wilson (2011), the 1976 local government reform empowered local government as a multi-purpose single tier of government and charged it with the responsibility of developing the rural area and the people thereby encouraging participatory democracy, mobilizing rural development and effective two-ways channel of communication. The reform also brought a unified local government system with defined functions and structure to achieve democratic governance irrespective of the state in Nigeria. Consequently, local governments were created for the first time in Nigeria to exercise democratic activities and provide for elections of the political actors at the 
grassroots (Obike and Nwaodu 2010 and Wilson, 2013). The reform also provided for the political control of the local government to be exercised by the councillors known as the supervisory councillors. Provisions were made for chairmen, elected and nominated councillors, fixed number of committees on finance and general purposes to serve as the cabinet members. As an organ of government, it is the principal forum for citizens' representation and the preeminent medium in which people seek to articulate their interest through their representatives.

\section{Challenges to Legislative Performance in Council Areas}

The following are some of the fundamental factors that affecting legislative performance at the grassroots in Nigeria. The state's exercise of unlimited jurisdiction is a major hurdle. The 1999 Constitution of Nigeria (as amended) saddles state governments with the power to organize elections into local governments through the State Independent Electoral Commission (SIEC) of that state. The slate governors appoint the chairpersons and members of SIECs. This, according to Omar (2012) has made the SlECs to be institutionally weak and susceptible to the manipulation of the appointing authority. Thus, conducts of local government elections do not satisfy the democratic will of the local people (Jawan, 2011 and Oni, Chidozie \& Agbude. 2013). It is implied that members of the legislature who emerges from undemocratic process would not be true representatives of the people. This is in tandem with Oni, Chidozie and Aghude (2013) position that in most cases, the candidates are handpicked by the state governor, imposed on the party, with state machinery deployed to ensure their victory at the polls. The poor electoral processes through which most legislators emerged at the grassroots make them to be lacking in capacity and skills to perform their oversight functions. Hence, their tenures arc often wasted at the expense of the masses. The implication of this is that activities of governments and the implementation of policies and programmes would not be investigated by the legislature to ascertain the extent to which they represented the peoples' interests. State's government incarcerated the councillors and hindered them from performing their functions effectively.

In many states, governors appoint local government chief executives by handpicking them instead of through credible polls. Many of such local government executives are given different names such as sole administrator, council manager, care- taker committee or transition committee. This was equally noted by Umor (2013) as a challenge to the development of local councils in Nigeria. According to Balogun (2012), out of thirty six states in Nigeria, very few states, among which are Enugu, Rivers, Jigawa and Lagos have their local governments run by duly elected representatives at different times. Successive governors in many states prefer to use appointees they personally handpicked to run local governments as against elected officers. Local councils in Osun and Oyo States have not had more than one time each of conducting elections into their local councils since the return of the civil rule in 1999. The running of local governments by sole administrators or caretaker committees throws away the legislative organ in the local government and consequently denied the people in the grassroots the opportunity of electing their representatives. The absence of legislative politics at the local level is nothing but an affront on the oversight function of the legislature. It also denies the "caged" councilors the training opportunity for political leadership that local democracy is meant to provide.

In a federal system like Nigeria, the ability of local governments to perform development functions revolves around the nature of the relationship between the federal, state and local government. The problem in this regard revolves around the extent to which the local governments are regarded truly as the third tier of the political structure or mere parts of the state governments. In Nigeria, the relevant constitutional provisions in respect of these relationships appear inadequate and unfavorable to the local government. For instance, the 1999 constitution of Nigeria (as amended) did not adequately provide for the financial autonomy of the local governments but subordinates them to the states. The provision of section 162, paragraph 6 does not allow direct funding of the local government from the federation account but the establishment and operation of State Local Government Joint Account. It is evident that state governments manipulate this constitutional provision to keep the local governments as their appendages and siphon the funds meant for them (Onah, 2004 and Ezeani, 2012). The interference in the local government financial autonomy accounts for their inability to initiate or execute development programmes on their own.

\section{Past Efforts at Re-positioning Local Governments in Nigeria}

Local Government system is traceable to the pre-colonial period when powerful empires and kingdoms existed in Nigeria's traditional societies. These traditional societies such as the Oyo Empire, Borno Empire, Sokoto Empire, Jukun Kingdom, Nupe Kingdom and Igala Kingdoms, among others, had other smaller districts, wards, towns and villages which were subjected to them. The subordinate governments which could he referred to as local government operated their own unique administration suitable for their cultural and religious needs and aspirations. The bulk of the administrative activities of these kingdoms and empires took place at local levels (Asaju, 2010). Specifically, the development of local government system can be traced to the Native Authority ordinance of 1916, which was passed by the British colonial government. The ordinance was the first legal framework to operatioalise a system of indirect rule. However, attempt to unify the system of local government 
was resisted from the East and West regions because of its anti-democratic nature and inability to fit into the existing traditional administrative systems in those regions. Notwithstanding, the ordinance was operational until 1946 when a new constitution was introduced. By 1949, the Eastern house of assembly provided a platform for debates that eventually led to the local government ordinance of 1950 , which set the scene for a democratic system of local government (Ogunna 1996). Thereafter, the country adopted federalism that made local government to be listed under residual matters with implication for the existence of different local government structures across the country (Adedokun, 2004).

In September 1973, the Public Service Review Commission under the chairmanship of Chief Jerome Udoji was set up. The commission among other things was charged with the responsibility of examining the organization structure and management of' the public service including local government services and recommends desirable reforms where necessary. The commission recommended the need to re-examining the whole structure of the local government system with a view to adopting a single tier system. Unfortunately, the government in power turned down the recommendation (Oyediran and Gboyega, 1981). In July 1975, the military regime included a systematic and deliberate reorganization of the local government in its programme and also provided for election into the local councils in a broadcast on October 1st, 1975.

In 1976 during the military administration of General Olusegun Obasanjo, the first major reform in local government system took place which formed the foundation of grassroots government today. The 1976 local government reforms introduced a system of uniform local administration throughout the whole country (Diejomoh and Eboh, 2010). The core aspect of the reforms was the democratization of the local government system which led to the increase in its autonomy both in functions and financial base. The new council was made up of a chairman and councilors who were to be elected for a definite term. In this respect, the reforms paved way for participation and involvement of people at the grassroots level in their local affairs (Asaju, 2010). As a tier of' government with constitutionally functions, it was entitled to a share of national revenue. Each local government was given 100 million naira during the 1976/77 financial year (Awotokun, 2005). For the purpose of viability, the $\mathrm{I} 976$ reforms also introduced a population criterion of between 150,000 and 800,000 people under which a local government could be created.

The 1970 constitution basically adopted and incorporated these reforms. The passage of the revenue allocation Act of 1981 entitled local government to I0\% of the federation account. The 1999 constitution preserves the tripartite system of government at the grassroots level. The executive organ consists of the local government chairman as the head, assisted by the vice-chairman, and empowered to implement policies with independence. The legislature is to be headed by a leader and equipped with independence to perform the role of' a parliament. They bare to represent the wards which make up the local government area and an independent judiciary which though is outside the jurisdiction of the local government and operating as a pall of the federal and state grill, avails itself of the judicial process in the local government (Awotokun, 2005). The presidential system is a structural framework that is believed to be serving the plural needs of Nigeria.

\section{Concluding Remarks}

A visible legislature is sine-qua-non for effective performance of third tier of government. Its absence is capable of derailing sustainable development at the grassroots in the country. Development and grassroots democracy cannot be entrenched when the legislative organ that supposed to be the heart of democratic consolidation at the local councils is completely absent. It is saddening to note that despite the numerous local government reforms in Nigeria, the legislature is yet to proactively deliver on its functions. The absence of democratically elected legislators in grassroots operations deny the people the opportunity of a robust representation that is germane for a modem state.

In view of the above, the followings are put forward as elixir for effective performance of the legislature at the grassroots. Local government councils should be granted 'real' constitutional autonomy by discontinuing the State-Local Government Joint Account. In addition, other forms of appointment into local councils that are undemocratic, and subjugate local councils to the discretion of state government should be discouraged. It is very important that the National Assembly follows up on its resolution of stopping monthly grants of local councils that are not having democratically elected members. The Ministry of Finance, Budget and Economic Planning should be made to compulsorily obey such resolution. In addition, running of local governments should be placed above party politics. The legislature should be allowed to perform its oversight functions in terms of project planning, monitoring, and control as provided for by the principle of checks and balances. In discharging its oversight functions, the legislature should eschew corruption to earn respect and preserve its dignity.

\section{References}

Adedayo, A. (2014). You Don’t Know Your Local Government Councillor? Well, You're Not Alone, September 25, Ynaija.com

Adedokun, A. A. (2004). The Development of Local Government in Nigeria Since Pre-colonial Era to 1999 , 
Polycom, 2 (2).

Adeoti, O. (2017). Participatory Governance and Grassroots Democracy in Nigeria, Nigerian Academic Journal, $5,80-92$.

Adeyemo, F.O. (2005). Contemporary Issues and Practices in Nigeria Local Government Administration. Enugu: Jones Communications Publishers.

Adeyemo, D. (2011). Optimizing Local Government Finance Through Public-Private Partnership. In Theory O. (Ed.) Key Issues in Local Government and Development: A Nigerian Perspective. Enugu: Praise House Publishers.

Alobo, E. (2014). Promoting the Culture of Democracy and Good Governance in Local Government Councils in Nigeria:: The Role of the Legislature.

Ani, B. et al. (2013). Advanced Local Government Finance, Enugu: Spring Time Press

Apata, Z.O. (2011). Creation of New Local Government in Kogi state: Problems and Prospectswest Yagha and Ijumu Examples. Crestill Publishers Ltd.

Asaju, K. (2010). Local Government Autonomy in Nigeria: Politics and Challenges of the 1999 Constitution. Lagos: Bookpoint Educational Ltd.

Awotokun, R. L. (2005). Local Government for Sustainable Development in Nigeria, International Journal Sustainable Development, 3 (2), 27-41.

Balogun, A. (2012). Local Government, Good Governance and Sustainable Development in Nigeria, International Journal of Sustainable Development, 5, 12-18.

Danjuma, A. (2012). Developing Alternatives Sources of' Funding Local Governments during the Period of Global Economic Recession, Journal of Business and Management, 2 (3).

Diejomaoh, I. and Eboh, E, (2010). Local Governments in Nigeria: Relevance and flctivetiess in Poverty Reduction and Economics Development, Journal of Economics and Sustainable Development, 1 (1), 12-28.

Ezeani, F. (2012). Fundamentals of Public Administration, Enugu: ZikChuks Publishers.

Haque, A. (2012). Theoretical Perspective of Local Government - Literature Review. Research Institute of Behavioural Psychology. MPRA Paper No. 46301.

Jawan, R. L. (2011). Local Government and Illegality. In Odion-Akhaine, S (Eds.) Local Government Administration in Nigeria. Abuja: Panaf Press.

Joshua, Segun \& Oni Samuel (2014). The Nigerian [louse of Representatives and War Against Corruption, (1999-2011), Mediterranean .Journal of Social Sciences. 5, (2).

Mishael, N. (2016,). Local Government Administration, Rationale, Challenges, and The Way Forward, Enugu: Nungkop Mishaci.

Obike, W. M. and Nwaodu, D. C. (2010). Local Government and Service Delivery in Nigeria,. Enugu: Nwamife Press.

Ogbuene, J. C. and Nzelibe, C.G.O. (1991). Improving Productivity in African Local Government System: A Comparative Analysis. In Nzelibe C. G. O. (Eds.) Current Issues in Local Government Administration Enugu: Fourth dimensions Ltd.

Ogunna, A.E.C. (1996). A Handbook of Local Government in Nigeria, Owerri: Versatile Publishers.

Omar, M. (2012). Ensuring Free, Fair and Credible Elections in Local Governments in Nigeria. Developing Country Studies, 2 (11), 75-81.

Onar, J. (2004). The Legislature and Representative Democracy in the Local Government System of Nigeria's Fourth Republic, Abuja: Baraka Press and Publishers Ltd.

Oni, S. Chidozie Felix C., Agbude A.G. (2013). Electoral Politics in the Fourth Republic of Nigeria's Democratic Governance: Developing Country Studies, 3(12), 48-56.

Orewa, G.O and Adewumi, J. B. (1992). Local government in Nigeria: The changing Scene'. Benin City: Ethiope Publishing Corporation.

Nwoba, T.; Ojo, K.M. and Tihen, C. (2015). Sole Administrator: A Challenge to Local Government Management in Nigeria. Journal of Public Administration and Local Government, 3(2), 67-78.

Oyediran, O. and Gboyega, A. E. (108 1). Local Government and Administration. In Oydiran, O. (Ed.) Nigerian Government and Politics Under Military Rule, London: The Macmillan Press Ltd.

Wilson, G. (2013). The Politics of Local Government Reforms and Democratic Governance in Nigerian Local Governments. Developing Country Studies, 3(1). 